International Journal Of Community Service

\title{
The Importance Of Fulfillment Of Parenting Patterns And Learning Culture In Pp Muhamadiyah, In Meri Village, Mojokerto
}

\author{
Solichah $^{1 *}$, Dwi Dewianawati ${ }^{2}$, Erry Setiawan ${ }^{3}$ \\ Mayjen Sungkono University, Faculty of Ecomonics, Mojokerto \\ ${ }^{*}$ Corresponding Author: \\ Email: sholihahh88@gmail.com
}

\begin{abstract}
.
Community service is carried out at PP Muhammadiyah Putri, Meri village, Mojokerto, with the aim of: 1) Supporting and strengthening the Covid-19 countermeasures and prevention programs carried out by the central and local governments. 2) Increasing the level of concern for Unimas academic citivity in accelerating prevention, transmission of Covit $-19,3)$ Lighten the burden on the community affected by covid -19 . Problems faced 1) Low school achievement of children who are left behind in PP Muhammidiyah Putri, 2) Low interest in learning children living in PP Muhammadiya Putri, 3). Less conducive learning environment, the method used in lectures and discussions. Programs implemented are 1) Child Development through Learning Culture, 2) Community Service, 3) Social Service, implemented smoothly as expected. Participants in the activity responded positively and expressed their gratitude to the academic activities of Unimas for providing useful knowledge to participants, namely fostering interest in learning to increase achievement, therefore hope that there is a continuation of the activity and it does not stop here
\end{abstract}

Keywords: Community service, parenting patterns, learning culture service work

\section{INTRODUCTION}

Real work lectures $(\mathrm{KKN})$ are a form of community service and this activity is important to be carried out as a form of concern and a form of participation from the academic community towards the surrounding environment. Based on data from the Indonesian Child Protection Commission (KPAI) in 2015 there were around 4,100,000 children in Indonesia who had been neglected, the data shows that children under five years of age or toddlers who are neglected are as many as 1,200,000 children, there are 34,000 street children who are not taken care of. This shows that the role and function of parents in caring for children is still not successful in reaching all children who are underage. Therefore, it is necessary to have institutions, agencies or foundations that are able to focus on children's problems when the role of parents in taking care of children cannot be felt by children who have been neglected. (source: http://www.kpai.go.id/berita/kpai-jutaananak-alami-masalah-sosial/). By law, the government has provided a place to accommodate abandoned children. This is stated in Law Number 23 of 2002 concerning Child Protection article 23 paragraph 1 that: "The state and government guarantee the protection, maintenance, and welfare of children with AntroUnairdotNet, Vol.VI/No.2/July 2017, page 225 considering the rights and obligations of parents, guardians, others who are legally responsible for the child.

In this $\mathrm{KKN}$, the researchers chose to focus on the Muhammadiyah women's orphanage, Meri. The researchers' interest in discussing "Parenting Patterns at the Muhammadiyah Putri Orphanage" is because this orphanage is also intended for children who are economically disadvantaged, underclass or underprivileged. The 
main problem that the researcher will examine is how to care for children at the Muhammadiyah orphanage in Meri Village, Mojokerto Regency. In the process of parenting, there is social interaction between caregivers and foster children. Like the concept of parenting put forward by Margaret Mead is learning cultures and teaching cultures, namely learning cultures and teaching cultures. Parenting that becomes this concept is informally carried out through learning cultures or the learning culture of children from childhood to adulthood which is applied in daily activities. The book Research Methods for Business (1994), states that if the research is directed at obtaining information that can be used to solve problems, then the research is called applied research, but if the research conducted is directed at understanding problems in depth within the organization (without wanting to apply the results) ) then it is called basic research. The research results obtained will be useful for the development of management science.

PP Muhammadiyah Putri, Meri was established as an educational institution that is free, does not take sides with any political party and does not belong to any of the mass organizations. Founded in 1938, its address is J1 Raya Meri no 524, Meri village, Kranggan district, Mojokerto city, East Java. The founder is Abah Sadeni, currently foster children number 20 female students, aged 13 to 22 years, education from junior high school, vocational school, college students. The number of caregivers is 1 person and the administrator is 8 people

Based on a survey conducted at PP Muhammadiyah Putri, it was found that the problems experienced by caregivers and caretakers were found. Namely: 1) The low school achievement of children who are left in PP Muhammadiya Putri, 2) Low interest in learning for children who live in PP Muhammadiya Putri, 3). Less conducive learning environment

From the description above, the research objectives are:

1. Support and strengthen the Covit-19 prevention and control program carried out by the central and local governments.

2. Increase the level of awareness of the Unimas academic community in accelerating the prevention of the transmission of Covid-19

3. Easing the burden on people affected by COVID-19

\section{METHODS}

The method in this research is descriptive, which is a writing in research that provides a description of the situation according to the data about the cultural subject under study, based on the actual situation at the time of the research process. descriptive explanations cannot show something statically about culture, descriptive explanations are able to explain feelings, phenomena, emotions from cultural subjects (Sugiyono 2009). In this study, the authors used qualitative data types. This type of qualitative data research is an empirical research that can be observed with the five senses according to real conditions, but on the basis of the expression of the research subject or informant. Time and place: Real Work Lecture (KKN) which is a community service conducted by PP Muhamdiyah Putri, Kelurahan: Meri. City: Mojokerto, Implementation Time: Saturday Implementation Date: 19 December 2020.

\section{Activity Recapitulation}

Table 1. Recapitulation of Group XV Community Service Program Activities

Mayjen Sungkono University, Mojokerto, Faculty of Economics

\begin{tabular}{|c|l|l|c|}
\hline No & \multicolumn{1}{|c|}{ Activity } & \multicolumn{1}{|c|}{ Aim } & Time \\
\hline \multirow{2}{*}{1} & \multirow{2}{*}{$\begin{array}{l}\text { Community } \\
\text { service }\end{array}$} & Cleaning the field & \multirow{2}{*}{$07.00-10.00$} \\
\cline { 2 - 3 } 2 & Social service & Cutting down trees & $10.00-12.00$ \\
\cline { 2 - 3 } & Giving groceries & Giving a veil (headscarf) & $04.00-06.00$ \\
\hline 3 & Counseling & Fajr prayer in congregation, reading the Qur'an, studying & \\
\hline
\end{tabular}

https://ijcsnet.id 
International Journal Of Community Service

\begin{tabular}{|l|l|c|}
\hline \multirow{2}{*}{} & $\begin{array}{l}\text { and picketing in the morning for school preparation, } \\
\text { breakfast }\end{array}$ & \\
\cline { 2 - 3 } & School, dhuhur prayer in congregation, lunch & $06.00-12.00$ \\
\hline & Lunch break & $12.00-15.00$ \\
\hline & $\begin{array}{l}\text { Asr prayer in congregation, afternoon picket, gardening, } \\
\text { sports, dinner }\end{array}$ & $15.00-18.00$ \\
\hline $\begin{array}{l}\text { Maghrib prayer in congregation, tajwid, memorizing } \\
\text { verses of the Qur'an, mengkadi Bulughul Maram book, } \\
\text { ishya prayer in congregation }\end{array}$ & $18.00-19.00$ \\
\hline Study, sleep at night, pray at night & $19.00-04.00$ \\
\hline & $\begin{array}{l}\text { Asr prayer in congregation, afternoon picket, gardening, } \\
\text { sports, dinner }\end{array}$ & $15.00-18.00$ \\
\hline
\end{tabular}

\section{Description of Activities}
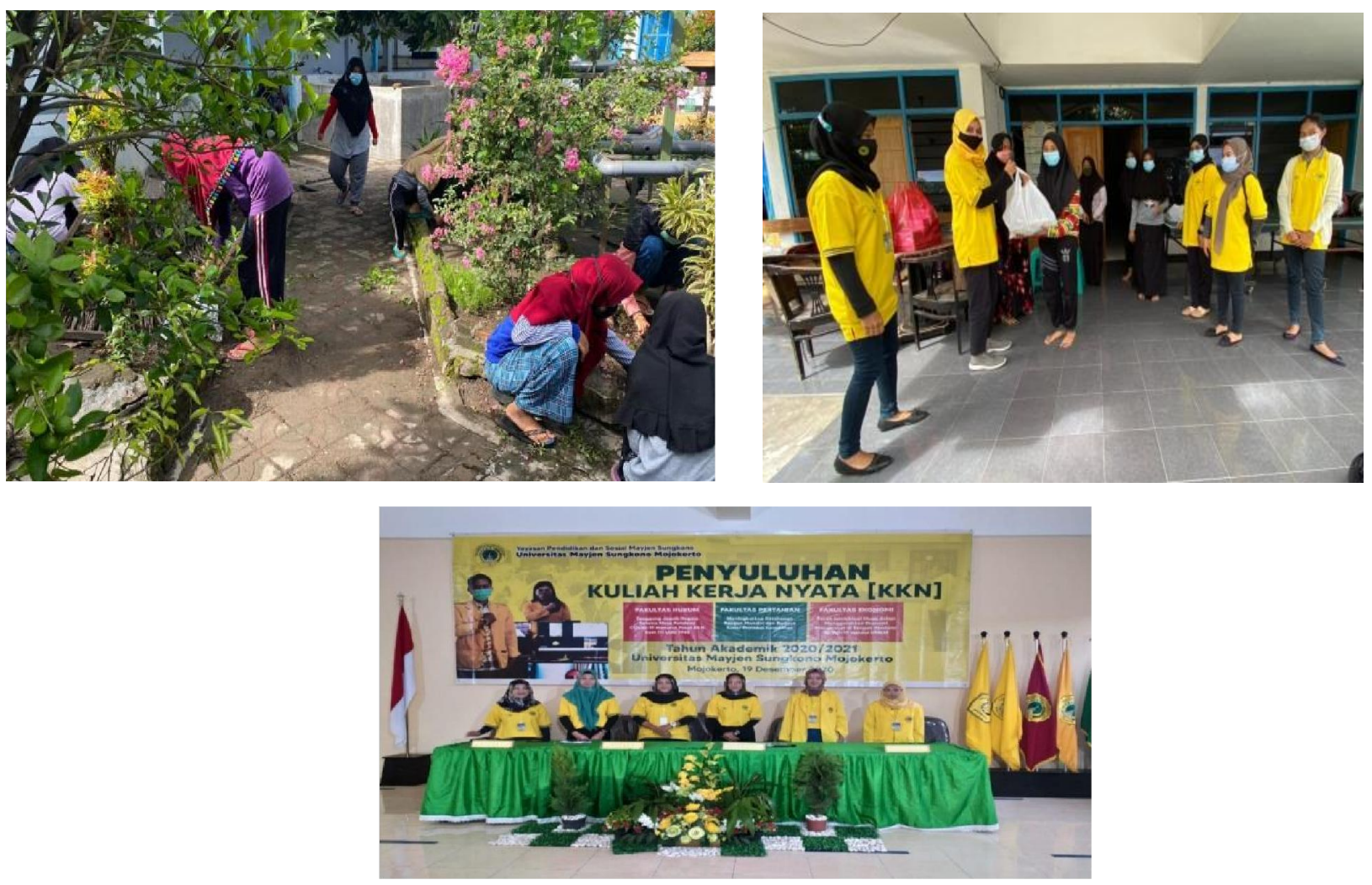

\section{RESULTS AND DISCUSSION}

The trial activity was carried out on December 19, 2020 and was welcomed by the administrators of PP Muhammdiyah Putri, and the opening of the activity began with introductions to everyone who lived in PP Muhammdiyah Putri. currently foster children amounted to 20 female students, from the age of 13 years to 22 years, education from junior high school, vocational school, college students. The number of caregivers is 1 person and the administrator is 8 peopleBased on the results of observational data (observations) and interviews, information was obtained regarding the description of the activities of foster children in the daily environment of the orphanage. A series of activity schedules for foster children have been made and agreed upon between the caretaker of the orphanage and the foster children. Of course, following the schedule of activities is an obligation for foster children when fostered at the Muhammadiyah Putri orphanage, Meri, Mojokerto Regency. The 
following is a series of activities for foster children which are summarized in the following table: Table 1 Recapitulation of Community Service Activities for Group XV, Mayjen Sungkono University, Mojokerto, Faculty of Economics The table above illustrates that the activities of foster children are active starting at 04.00 WIB, namely at dawn.

Before the dawn call to prayer, children are required to wake up early at $04.00 \mathrm{WIB}$. It is the caretaker of the orphanage who is in charge of waking the foster children every day, the foster children immediately get up, clean the bed, wake each other's roommates to get up and tidy up the room. Entering the dawn, children who get a schedule to call the call to prayer immediately carry out their duties. After the call to prayer sounded, the foster children and caregivers gathered to perform the morning prayer in congregation in the mosque. When the obligation to carry out the morning prayer in congregation is complete, the foster children continue to read the Koran. After that, some of the children did picket in the morning to clean the prayer room, bathroom or WC (water closet), sweep the yard, mop the floor and some children study and prepare books to take to school. Then, they continue to clean their bodies or take a bath, then have breakfast (breakfast) together and then go to their respective schools.

Children spend their time at school from morning to afternoon, some children who are in elementary school (SD) and junior high school (SMP) have an earlier time to go home from school than children who are in middle school. Upper (high school) and college level. For foster children who are in the orphanage, they will perform the midday prayer and lunch at $12.00 \mathrm{WIB}$ at the orphanage. At $12.00 \mathrm{WIB}-15.00 \mathrm{WIB}$, foster children who are in the orphanage are freed to carry out other activities, such as playing in the orphanage environment, playing outside the orphanage environment (with the permission of the caregiver), studying, napping and others. Entering 15.00 WIB, the foster children who are in the orphanage will get ready to perform the Asr prayer obligations, the preparation is usually done by cleaning the body (bathing). Then, it was continued with the foster children who had their turn to say the call to prayer, and all the foster children and caregivers who were in the orphanage prayed.

\section{Child Development through Learning Culture}

learning culture at PP Muhammadiyah Putri, Meri can be categorized as follows:

Knowledge and Skills Development. At PP Muhammadiyah Putri, there is the provision of knowledge and skills for foster children. It aims to carry out parenting by improving the quality of development and growth of foster children at the Muhammadiyah Putri orphanage, the administrators and caregivers strongly support the development of children's education with care in formal institutions. This proves that there is a teaching culture through effective formal education as evidenced by the placement of foster children at the elementary school (SD) to tertiary level in Mojokerto Regency. In daily activities, foster children are given guidance and direction to train their interests and talents in the field of entrepreneurship. This is realized by the Muhammadiyah Putri orphanage by holding an independent business. In the implementation of this training, it is included in the category of learning culture or what is called learning cultures, which is the transfer of cultural values through the daily activities of foster children.

In an effort to educate foster children in accordance with the values adopted by the Muhammadiyah Putri orphanage, agreed rules have been made between the caretaker of the orphanage and the foster children when they meet the requirements to enter the Muhammadiyah Putri orphanage. If there is a violation regarding the prohibition that children do, the administrator of the Muhammadiyah Putri orphanage becomes the party that determines the consequences or sanctions that must be received by the children who violate it. Considerations regarding the sanctions obtained are also on the effect of what violations were committed and the age of the foster children who violated these rules. If foster children violate at the elementary and junior high school levels, the orphanage administrator will give advice in a subtle way or with punishment media such as not getting 
pocket money for a certain period of time. However, if a child violates the rules of high school and college, a warning will be given in the form of a warning at an early stage, additional work to clean the room in the orphanage, and if the child still violates it again, the caregiver will not be ignored by the caregiver within a week or so. It is possible that the orphanage administrator will confine the child by not being outside the orphanage for a certain period of time. Of course there is no element of violence that caregivers do when foster children do this. The orphanage regulations are made to train children's discipline. The regulation has even been posted on the walls of the orphanage to remind the foster children. The absence of physical violence that causes psychological trauma has indeed become a patent application in the female Muhammadiyah orphanage, namely caring for foster children with love through Islamic values and realizing foster children's mentality with independence.

\section{Community Service Activities Clean the Environment}

One of the cultures that become the identity of the village community is community service. This activity is usually carried out by the surrounding community together, with the aim of carrying out certain activities, one of which is community service aimed at building infrastructure or cleaning the surrounding environment which is carried out in mutual cooperation at PP Muhamadiya Putri, especially community service is still often carried out even though its implementation is not routine every year. week or every month, such as building road rebates, cleaning roads or the surrounding environment, cleaning irrigation canals and other activities. Coinciding with last Saturday, December 18, 2020, together with PP Muhadiyah Putri management and KKN University students, Major General Sungkono, especially group 15, they carried out community service activities to clean PP Muhadiyah Putri's yard and environment.

Community service to clean the environment is carried out to create a healthy environment, free from dirt, garbage and grass, trees that are already lush. With a healthy environment, we will not be susceptible to various diseases. Environmental cleanliness is also very influential on the comfort, beauty and beauty of the environment. The purpose of holding this clean-up activity is to clean the PP Muhadiyah Putri environment so that it is always beautiful and comfortable for all of us. Because in the transitional season like the Covid-19, many diseases arise, so by holding activities like this, at least we can reduce the source of disease from a dirty environment. In addition to maintaining cleanliness, this activity also aims to foster social relations. the community, especially in PP Muhadiyah Putri, he explained. The activity starts at $07.00 \mathrm{WIB}$.

\section{Social Service Activities}

On Saturday, December 19, 2020, Mayjen Sungkono University, Faculty of Economics held a social service activity at PP. Muhadiyah Putri, Meri Village, Mojokerto Regency. The activity with the theme The role of young intellectuals in driving the community's economy in the midst of a pandemic through SMEs, was organized by KKN Mahsiswa, Faculty of Economics As shown in Table .1. Recapitulation of Community Service Activities for Group XV at the University of Mayjen Sungkono, Mojokerto, Faculty of Economics, that the activity which started at 07:00 WIB to 12:00 WIB was aimed at helping the community there and to increase social sense and showed that the University of Mayjen Sungkono, Faculty of Economics, did not not only excels in academics, but is also active in social activities.

PP. Muhadiyah Putri, was very enthusiastic in following her and was happy because she had been helped. It is evident from the PP Muhadiyah Putri foundation, welcoming the arrival of KKN students, group $\mathrm{XV}$, this activity also received a positive response from the surrounding community including from the local government (Mayor of Mojokerto)With the distribution of basic necessities, hijabs, it is hoped that it will help the economic situation at PP Muhamdiyah Putri a little. The activities that day went smoothly and could be a lesson for KKN students, group XV about the lives of the people around them 


\section{CONCLUSION}

Conclusion Fulfillment of parenting patterns with learning culture is evidenced by the administrators and caregivers who realize the development of children's education by parenting in formal institutions. This proves that there is a learning culture or teaching cultures through effective formal education as evidenced by the placement of foster children at the elementary school (SD) to tertiary level. Meanwhile, the manifestation of the existence of a learning culture is seen in the Muhammadiyah orphanage holding an independent business. In the implementation of this business skills training, it belongs to the category of learning culture or so-called learning cultures which is the transfer of cultural values through the daily activities of foster children. In the findings that the researchers conducted in the field, data were obtained that the administrators and caretakers of the Muhammadiyah Putri orphanage not only wanted to improve the quality of foster children's education but also had intrinsic goals.

The administrators and caretakers of the Muhammadiyah Putri orphanage really hope that the foster children do not depend on the Muhammadiyah Putri orphanage for their lives continuously, but also behave and have an independent mindset when the children reach adulthood, this is done so that the children are able to give reciprocity. to the orphanage either through mentoring their younger siblings or material or money when they are already alumni of the orphanage. The results of the personality formed from the upbringing of the Muhammadiyah Putri orphanage are thick with the values of independence in entrepreneurship. The emergence of these attitudes is the result of the process of parenting children in the orphanage that has been undertaken so far. There is knowledge development

\section{ACKNOWLEDGMENTS}

Thank you to the management and children of the Muhamadiyah Putri Islamic Boarding School in Meri Village, Mojokerto. Who has enthusiastically and cooperated with the Academic Citivas of Univ. Major General Sungkono Mojokerto in carrying out community service activities

\section{REFERENCES}

[1] Basnur, R.R. 2014. Orang Tua yang Menitipkan Anak ke Panti Asuhan di Surabaya (Studi Tentang Penelantaran di Surabaya). Universitas Airlangga.

[2] Komisi Perlindungan Anak Indonesia .2015. KPAI : Jutaan Anak Alami Masalah Sosial. [Diakses 27 September 2016]. http://www.kpai.go.id/berita/kpaijutaan-anak-alami-masalah-sosial/.

[3] Manan, I. 1989. Antropologi Pendidikan. Jakarta: P2LPTK.

[4] Mulyana, D. 2004. Metodologi Penelitian Kualitatif: Paradigma Baru Ilmu. Komunikasi dan Ilmu Sosial Lainnya. Bandung: Remaja Rosdakarya.

[5] Republik Indonesia. 2002. UndangUndang No.23 Tahun 2002 tentang Perlindungan Anak. Lembaran Negara RI Tahun 2002, No. 109. Sekretariat Negara. Jakarta.

[6] Sugiyono. 2009. Metode Penelitian Bisnis (Pendekatan Kuantitatif, Kualitatif, dan R\&D). Bandung: Alfabeta. 